\title{
Preparing the Forester for Pest Management - A View from Provincial Government 1
}

\author{
by
}

R.F. DeBoo²

\begin{abstract}
Development of forest pest management capability within the BC Forest Service is outlined. Appropriate specialized professional training of staff is emphasized. The ability to manage provincial forests must be based on a blend of inputs from forestry generalists and specialists. Greater awareness of the need for pest management and solution of our weaknesses in pest management training depend largely on more emphasis being given to it in our academic establishments. Recommendtions are made.
\end{abstract}

\begin{abstract}
Résumé
Le développement de la capacité de gérer les agents nuisibles des forêts au sein du Service forestier de la C.B. est abordé. La formation adéquate, spécialisée et professionnelle du personnel est soulignée. L'habileté à aménager les forêts provinciales doit reposée sur un mélange d'intrants provenant des généralistes et des spécialistes en foresterie. Une sensibilisation plus grande en fonction des agents nuisibles et une solution aux faiblesses dans la formation en aménagement selon les agents nuisibles dépendent beaucoup d'une plus grande emphase entreprise lors de toute formation académique. Des recommandations sont présentées.
\end{abstract}

\section{Background}

Forest pest management in British Columbia was recognized formally by the provincial government after structural reorganization of the Forest Service and enactment of new forest and range legislation in 1979. Until then, pest situations were dealt with only intermittently and on the advice of scientists, academics and a few friendly Americans.

Formation of the forest pest management team commenced in 1980. Staffing efforts continued to 1985 , including throughout an extended and very difficult period of staff reduction that saw Forest Service ranks shrink from near 5500 to fewer than 4000 employees. Today, the BC Forest Service retains the services of professional entomologists, pathologists, and post-graduate specialists in pesticide use, weed management, nursery pests, and seed and cone pest management. As well, about half of the Forest Service's 46 district offices have dedicated pest management personnel.

As background for this CIF Workshop, I expect British Columbia's recent initiative in forest pest management might be considered as the Canadian model for integrating pest and forest management practices. In effect, the new staff members, now numbering about 50 (vs. one prior to 1980), are intimately involved in planning, conducting, monitoring, assessing, and improving operations in forest management. All of this came about because of a trio of insistent and persistent resident educators and a few far-sighted members

\footnotetext{
Paper presented at the Annual Meeting of the Canadian Institute of Forestry. Joint Forest Protection and Forest Education Workshop, Victoria, B.C. 23 September 1986.

2Manager, Pest Management, Protection Branch, B.C. Forest Service, Victoria B.C., V8W $3 E 7$.

${ }^{3}$ Association of British Columbia Professional Foresters.
}

of the Forest Service. Although I have worked in eastern and central Canada and in the United States, my perspective is tempered largely by this special view from Victoria which I shall share with you today.

\section{Generalists and Specialists}

Professional pest management positions at Branch and Regional Office levels require: (1) post-graduate training, (2) extended related work experience, and (3) eligibility for registration in the Association of British Columbia Professional Foresters. These requirements have been established because of the recognition for special input for planning and leadership in complicated and often controversial pest management projects. At the same time, the requirement for specialty training is bolstered by the RPF requirement which demands a basic forestry knowledge as well.

As a result of these standards, professional Forest Service pest management staff are graduates of MS, MSF, MPM (Master of Pest Management from Simon Fraser University) programs and a few hold $\mathrm{PhD}$ degrees as well as the accrediting RPF credentials. Technical and other support staff are graduates of forestry and biological programs (BSc level) or from technical forestry or natural resources schools. Pest management staff are considered qualified for dealing with the planning and subsequent activities to either suppress or prevent pest losses. We believe, through growing involvement and collaboration, the pest management specialist is fast becoming one of the most important contributors and valued associates for designing processes to improve forest management practices. 
Whereas we consider the specialized pest management staff basically competent in forestry, forestry school graduates are not necessarily competent or comfortable when dealing with pests. It is my understanding that current Canadian university graduates are receiving basic exposure (if at all) at about the same meagre dose most classmates had when I graduated from UNB in 1960. That is, a token $1 / 3$ to $1 /$ 2 semester short course on insects, diseases, and related pests, with a few junior and senior class courses being offered to a few interested students. Weed management courses for foresters are only now being discussed, designed and taught. This dilemma is particularly perplexing when our forecast shortages in wood supply are considered and in contemplating the major team effort and cast of characters that will be required to truly manage our forests. It is also quite surprising at times to hear foresters define "pest" and "pest management".

To rectify the training deficiencies, as we see them, the Forest Service has just received an internal Task Force report (Muir et al 1986) which suggests developing our own training modules for special functions such as pest detection, damage appraisal and control operations. In addition to these proposals, the Forest Service already conducts 10-15 fourday pesticide applicator courses annually. These result from their general unavailability elsewhere and because of the sensitive and demanding nature of herbicide and insecticide applications according to B.C.'s strict Crown land permitting process.

Post-university or technical college-type training is also sponsored by the $\mathrm{ABCPF}^{3}$, particularly for individuals seeking registration and to satisfy requirements for certain positions (e.g., entomologist, pathologist). Thus, courses that might not be available "up front" at universities and technical schools usually can be picked up elsewhere to satisfy the needs of the line or staff employee specializing in pest control. This forestry situation in British Columbia is not necessarily acceptable nor commendable, but again from my jaded perspective, it is probably better than anywhere else in the country.

\section{Summary and Recommendations}

Our situation and experience in British Columbia, although perhaps unique regarding staffing, probably reflect most pest management scenarios elsewhere. We have observed that graduate foresters, without special training and experience, may be inadequately equipped to deal with many pest situations. Thus, concerns about root diseases, small mammals, dwarf mistletoes, bark beetles, stem rusts, and so on may be incompletely addressed by forestry generalists in planning and implementing field operations. Only in the areas of weeds and insect defoliators has there been traditional involvement of a few specially trained individuals across Canada.

The BC Forest Service has taken the initiative to ensure local input from trained and experienced resident specialists to improve operations against all major pests while providing supplementary training for critical functions as well. This situation is unique in Canada at present.

As forest management in this country is largely a provincial responsibility, the ability to manage provincial forests must be based on a blend of inputs from forestry generalists and specialists at both staff and line levels of responsibility. Recent initiatives in British Columbia suggest that forestry educators might consider:

(1) A basic and prerequisite first- or second-year course in forest pest management to include introduction to major pests, pest management methods, linkages to forest planning, inventory, mensuration, research, silviculture, and other operational disciplines.

(2) Special training needs such as pertinent sessions on regulation and use of pesticides, aerial and ground surveys, techniques to appraise damage, major control strategies (such as spraying, priorized logging, site preparation treatments), pest management information systems.

(3) Closer liaison with local protection, silvicultural and pest management staff with intentions to determine and address operational priorities and deficiencies.

In conclusion, I believe the solution to our weakness in pest management training, and thus in our ability to deal with pests, is predicated on some basic refurbishing at our academic establishments and not solely on the vigorous new efforts of major employers such as the BC Forest Service. Together, we might at least bury uninformed or uncaring attitudes, which may prevail at times, by blending efforts from forestry generalists with the inputs from the fringe disciplines (Stark 1982). This need is particularly obvious at the planning stage.

To do this, educators and employers will have to work hard and face up to the re-education of:

- paper preoccupied researchers,

- inward-thinking academics,

- segmented, blinkered or brainwashed managers, and

- turf-protecting practising foresters

Richmond (1986), a unique combination general forester and pest specialist for over 60 years, has advised: "No longer do we subscribe to the nozzle-head control philosophy so pronounced ... in the 1940's and 50's. This has given way to an entirely new, environmentally compatible and permanently effective concept of pest control through good management." Given this sort of educational background and the right employment atmosphere, the student seeking a forestry diploma might then appreciate the mandate and importance of pest management colleagues. Until then, his/her education will be incomplete and the integration of pest management into the forestry mainstream will probably be slow and painful for pest specialists particularly.

\section{References}

Muir, J.M., P.M. Wood and D. Gray. 1986. A review of pest management training needs in the BC Forest Service. BC For. Serv. Int. Rep. PM-PB-24. 11 p.

Richmond, H.A. 1986. Forest entomology: from pack horse to helicopter. BC For. Serv. Pest Manage. Rep. No. 8, 53 p. (In press.)

Stark, R.W. 1982. Applying research results from "fringe disciplines": Lessons learned from integrated pest management RD \& A programs. In Technology Transfer in Forestry. UK For. Comm. Bul. 61. pp. 32-37. 